\title{
Forskønnede forbilleder i peer- support
}

\author{
Om hvordan forsøget på at være "det gode \\ eksempel" kan skabe urealistiske billeder af \\ recovery $i$ mental sundhed
}

Natasja Eilerskov Jensen

Cand.scient.anth. med speciale i medicinsk antropologi, fra Aarhus Universitet natasja.mail@hotmail.com

Jensen, Natasja Eilerskov. 2021. Forskønnede forbilleder i peer-support: Om hvordan forsøget på at være "det gode eksempel" kan skabe urealistiske billeder af recovery. Tidsskrift for Forskning i Sygdom og Samfund, nr. 35, 51-72

Denne artikel er et empirisk bidrag, som illustrerer dele af et decentraliseret sundhedssystem, der har en recovery-orienteret tilgang til psykisk sygdom. Den er baseret på 4,5 måneders feltarbejde $i$ Vancouver, der fandt sted $i$ den verdensomspændende mentale sundhedsorganisation Clubhouse (ogsa kendt som Fountain House). Artiklen fremhæver, hvordan "recovery" indeholder en dobbelthed, da "recovery" både rummer muligheden for at fä en bedre (en "mere produktiv og meningsfuld") fremtid, men samtidig bliver denne mulighed til et krav. Baseret på deltagerobservation og interviews med personale og medlemmer undersøger denne artikel, hvordan personalet føler sig forpligtet til at regulere og begrænse sig selv og træk ved deres psykiske sygdom for at kunne leve op til den standard for "selvkontrol", som de skal lære medlemmerne gennem recovery-processen. Jeg argumenterer for, at handlingen af at skjule en bestemt adfærd gør personalet til et forskønnet - og dermed misvisende - peer-forbillede. Jeg påpeger, at denne misvisende forskønnelse kan skabe en urealistisk standard for, hvad det vil sige at leve med psykisk sygdom. Artiklen lægger således op til at overveje, om vi, ved at acceptere at nogle mennesker evner recovery, og 
andre ikke gør, ligeledes fjerner incitamentet til at lede efter årsager og forbedringer udenfor individet.

\section{Beautified role models in peer support: On how attempts of being "the good example" can create unrealistic images of recovery in mental healthcare}

This article is an empirical contribution that illustrates a bureaucratic healthcare system, which takes a recovery-oriented approach to mental illness. It is based on 4,5 months of fieldwork in Vancouver within the worldwide mental health organisation Clubhouse (also known as Fountain House). The article highlights how "recovery" becomes twofold, as it holds both the possibilities for a better (a "more productive and meaningful") future, but with this possibility follows a demand. Based on participant observation and interviews with both staff and members of the Clubhouse, this article investigates how the staff is required to regulate and restrict themselves and their mental illness, in order to live up to the same "self-control", they ought to teach members as part of their recovery. I demonstrate how these self-regulations of staff entail hiding traits of their mental illness. I argue that hiding certain behaviour creates a beatified - yet misleading - version of staff within the peer role. I point out that this misleading beautification can set an unrealistic standard for what it means to live with mental illness. The article thus sets out to consider whether, by accepting that some people can manage recovery, and others cannot, we furthermore remove the incentive for examining causes and improvements outside the individual.

\section{Introduktion}

Jeg har selv kæmpet med psykisk sygdom, og jeg har fundet forskellige måder at kunne håndtere det på. Det meste af vores klientel har ikke lært, hvordan de skal fungere på trods af deres psykiske sygdomme. Jeg håber, at jeg, ved at være her og igennem min erfaring, kan hjælpe dem til at få de samme fxrdigheder, som jeg har. (Ethan, personale i Clubhouse)

Denne artikel handler om et canadisk behandlingstilbud, et Clubhouse, der har til formål at hjælpe mennesker med psykisk sygdom tilbage til et normalt liv. Alligevel er afsættet for artiklen, at der er uoverensstemmelse mellem den givne organisations ønske om at opnå recovery ved at bruge de ansatte som peer-forbilleder, og hvad der faktisk er den empiriske virkelighed. I Clubhouse forstås reco- 
very som, at mennesker med psykisk sygdom lærer, hvordan de kan leve "aktive, produktive, og assimilerede liv i samfundet" (Doyle, 2013: xvi). I stedet for at komme tilbage til samfundet er mange af organisationens brugere - som går under navnet "medlemmer" - en del af organisationen i 15-30 år. Det er formodentligt ikke overraskende, at der kan være udfordringer ved at reintegrere mennesker med psykisk sygdom i samfundet efter deres recovery-behandling, og dette har uden tvivl mange mulige årsagsforklaringer. Artiklen her er dog ikke et forsøg på en sådan årsagsforklaring. I stedet udspringer artiklen af en undren over, hvorfor hverken medlemmer eller ansatte afsøger en forklaring på, at mange medlemmer ikke kommer tilbage i samfundet men i stedet lever deres liv indeni Clubhouse? Som jeg skal præsentere senere i artiklen, bliver forklaringen fra personalet, "at nogle mennesker har brug for recovery længere end andre". Årsagen hertil forstås dermed som noget, der kommer inde fra det pågældende individ, snarere end ude fra det omkringliggende samfund. Når denne artikel ikke diskuterer de strukturelle omstændigheder, der ligeledes er med til at fastholde medlemmerne i organisationen uden at gennemgå recovery, er det altså ikke et udtryk for, at strukturelle omstændigheder er uden betydning. En sådan diskussion vil tilhøre en anden artikel men forholder sig blandt andet til dobbelte problematikker, såsom hjemløshed og misbrugsproblemer, som begge er presserende problematikker for denne organisation. Artiklens fokus afspejler altså i stedet det forundrende ved, at man i Clubhouse undlader at fokusere på og forklare de lange medlemsskaber i lyset af strukturelle udfordringer som hjemløshed og dobbeltdiagnoser, der ligeledes tilkommer mange af medlemmerne. Artiklen bevæger sig derfor dybere ind i interaktionen mellem ansatte og medlemmer, og hvordan denne interaktion forholder sig til, lever med og uagtsomt kommer til at acceptere og derved reproducere ovennævite strukturelle fastholdelse.

I bogen Fountain House: Creating Community in Mental Health Practice beskriver organisationens undervisningsdirektør, Alan Doyle, den generelle metode og intention bag Clubhouse eller Fountain House/Fontænehuset, der i dag har mere end 300 filialer verden over. Et Clubhouse bygger på et tæt samarbejde mellem personale og medlemmer, hvor den ansatte i samarbejde med medlemmet skal udføre det daglige arbejde i organisationen. Det kan være madlavning, skrive nyhedsbreve, tjekke op på andre medlemmer, opdatering af medlemsinfo, havearbejde og lignende. Herved kan medlemmet både forbedre sine kompetencer og skabe meningsfulde relationer med personalet, der har i sinde at simulere for medlemmet, hvordan man bliver klar til livet udenfor organisationen med de forventninger, relationer og ansvar, der medfølger (Doyle, 2013: xvi). Et Clubhouse 
bygger oprindeligt ikke på en peer-support tanke, og egen erfaring er ikke et formelt krav for ansættelse. De ansatte i Clubhouse er heller ikke frivillige, men får løn, modsat mange andre peer-supportere. Alligevel forstås levet erfaring som en fordel, der med fordel kan benyttes. I det empiriske grundlag for denne artikel har alle de ansatte selv en psykiatrisk diagnose (depression eller angst). Dette er ifølge personalet en fordel, da de mener, at det fører til en gensidig forståelse med medlemmerne. Problemet er blot, at medlemmerne aldrig oplever, at personalet står overfor de samme udfordringer som dem selv. Personalet skjuler deres udfordringer med sygdommene, hvor de eksempelvis gemmer sig i eller forlader Clubhouse-bygningen i angst. Man kunne argumentere for, at personalet netop er i selvkontrol og derved demonstrerer for medlemmet, at det er muligt at leve i kontrol over sin sygdom, når de trækker sig tilbage i kølvandet på et angstanfald. Problemet er, at personalet skjuler hele denne handling for at fremstå i kontrol overfor medlemmer og deres kollegaer. Denne handling betegnes i artiklen som en forskønnelsesproces, hvor personalet præsenterer sig selv som et forskønnet forbillede, der altså er et analytisk resultat. Artiklen ønsker derfor at problematisere en diskrepans mellem ønsket om lighed og håndhævelsen af forskelle. På den ene side er der lighedsskabende elementer i både peer-support, hvor både den, der giver og modtager hjælp, har samme problematik (psykisk sygdom), og ved recovery som en praksis, der demonstrerer, at man kan komme tilbage til samfundet og et almindeligt, produktivt og assimileret liv. Begge disse hævdes at være grundelementer i Clubhouse. På den anden side skjules de i praksis, hvilket efterlader forskelle mellem personale og medlemmer. Disse forskelle risikerer at afføde spørgsmål som: hvorfor kan personalet være upåvirkede af deres sygdom, når medlemmet ikke er? Denne artikel fremsætter således et argument om, at kombinationen af at hævde lighed mellem personale og medlemmer i en fortælling om, at begge grupper lider af psykisk sygdom, men samtidig at skjule de udfordringer personalet oplever, kan fremsætte et urealistisk billede af, hvad det vil sige at have opnået recovery. Det ligner altså, at recovery betyder at være upåvirket snarere end at have strategier til at afhjælpe situationer, hvor også personalet er meget påvirkede af deres sygdom. Derudover er dette en anledning til at overveje, om man, ved at fokusere på den lighed, der ligger i at begge grupper har en sygdom, begrænser forklaringsmulighederne for, hvorfor medlemmerne i større grad ikke udviser samme selvkontrol. Den forskel der gør, at nogen lykkes med recovery, og andre ikke gør, kan derfor risikere kun at kunne forklares indad. På baggrund af analysen stiller artiklen spørgsmålstegn ved, hvorvidt konsekvensen af at begrunde manglende recovery med et individ, der ikke evner det, bliver en accept 
af, at mange forbliver medlemmer i 15-30 år og altså ikke reintegreres i samfundet. Ved at accepterer dette mangler vi således en grund til at undersøge, om faktorer udenfor individet ligeledes kunne spille en rolle for den manglende reintegration.

\section{Teoretisk kontekst}

I dette studies empiriske felt; en recovery-orienteret organisationen med fokus på mental sundhed, defineres "recovery" som evnen til at leve et normalt og selvforsørgende liv (Doyle, 2013: 158). "Recovery" må ligeledes forstås som et paradigme, der tror på, at mennesker med "alvorlig psykisk sygdom" har og skal have muligheden for, og retten til, at kunne genskabe et meningsfuldt og produktivt liv (Rakfeldt et al., 2009: 3). Recovery er særligt blevet problematiseret fra et neoliberalt perspektiv (Rose, 1996; Harper \& Speed, 2012; Rakfeldt et al., 2009), hvor det blandt andet beskrives, at et individ, der er i recovery, forventes at være medaktør snarere end en "passiv modtager af rehabiliterings-tilbud" (Deegan, 1988). Recovery-processen har til formål, at lade det pågældende individ forstå sig selv på ny med de nye muligheder, der rækker udover de begrænsninger, som sygdommen giver dem (bid.). Recovery er tilmed mange steder blevet praktiseret som en del af decentraliseringen af mental sundhed, der siden de tidlige 1960'ere var særligt fremtrædende i Vesteuropa, USA, Australien og Canada (Ronquillo, 2009: 11, 13). I Vancouver begyndte decentraliseringen i 1979, hvor man arbejdede hen imod regionsbaserede tilbud (Ronquillo, 2009: 15) som eksempelvis Clubhouse. Det var dog ikke før de tidlige 1990'ere, at transformationen for alvor satte ind, og Vancouver's store psykiatriske hospital Riverview Hospital lukkede således først helt for behandling i 2012 (ibid.: 17).

Denne artikel er et bidrag til forståelsen af mennesker, hvis adfærd og levemåde falder udenfor fremherskende normer i samfundet. De er andetsteds blevet beskrevet som "problem-identiteter", der beskriver individer, hvis levemåde skaber komplikationer i interaktionen med pågældende normer i samfundet (MikMeyer \& Järvingen, 2003: 12). For at kunne modtage hjælp må de tilknyttes en kategorisering af et problem, altså en problem-identitet (ibid.). I artiklens konkrete empiri drejer det sig om mennesker, der vedkender sig at lide af psykisk sygdom, eftersom man ikke kan være medlem af et Clubhouse uden en psykiatrisk diagnose. Når man er medlem, er organisationen behjælpelig med at skabe adgang bolig, arbejde osv., hvilket ofte er sameksisterende problematikker for denne gruppe mennesker (jf. Doyle, 2013: xvii). 
Artiklen indskriver sig i en litteratur, der beskæftiger sig med, hvordan subjektiviteter er forankret i institutioner og organisationer (jf. Mik-Meyer \& Järvingen, 2003; Hacking, 1986; Gubrium \& Holstein, 2001; Holstein \& Miller, 1993; Bjerge \& Nielsen, 2014). Begreber som 'dual issues' eller 'dual diagnosis'/' dobbeltdiagnoser' er blevet brugt til at beskrive problematikker, hvor behandlingen af psykisk sygdom, hjemløshed og/eller stofmisbrug bliver kompliceret i praksis, fordi behandlingen af dem forstås og praktiseres adskilt (jf. Bjerge \& Oute, 2017). Lignende er tilfældet for denne artikels empiri, da fokusset på mental sundhed i Clubhouse netop ikke imødekommer behandlingen af andre problematikker i praksis.

Artiklen indgår derudover i en analytisk diskussion af tilblivelsen af mennesket som et subjekt, der er placeret i en magtstruktur, hvori individet styres ved at få vedkommende til at styre sig selv (jf. 'conduct of conducts' i Foucault , 1985 samt 'Governmentality' i Foucault, 1991). I en recovery-baseret behandlingsstruktur kan subjektet modtage hjælp, hvis vedkommende frivilligt ønsker at ændre sin adfærd og indgå i diverse behandlingstilbud (jf. Rose, 1996). Det er indenfor denne struktur og subjektivisering, at artiklen peger på, hvordan nogen (måske utilsigtet) fastholdes i recovery.

\section{Lokal baggrund}

I Vancouver findes en række forskellige organisationer, som understøtter mennesker, der lider af psykisk sygdom eller stofmisbrug samt herberger for byens hjemløse. De fleste af disse organisationer er placeret i bydelen kendt som "The Downtown Eastside", der i 2019 var "hjem" for 62\% af de hjemløse i Vancouver (Marshall, 2019: 10). Selvom Clubhouse er placeret i udkanten af byen, er mange af dets medlemmer alligevel forbundet til "The Downtown Eastside". Fra organisationens begyndelse i 1940'erne har det været en del af fortællingen, at deinstitutionaliseringen af psykisk sygdom førte til øget hjem- og arbejdsløshed for de tidligere patienter, fordi de, der før boede på psykiatriske hospitaler, nu skulle reintegreres i samfundet (Doyle, 2013: xiv). Clubhouse blev bl.a. stiftet for at afhjælpe denne problemstilling, og hjemløshed er stadig et stort problem for psykisk syge mere end 70 år efter det første Clubhouse åbnede i New York i 1948. Som medlem af et Clubhouse kan man derfor få adgang til sociale boligbyggerier, der omtales "lavpris lejligheder", og som ejes af Clubhouse. Samtidig tilbyder organisationen boligstøtte ${ }^{1}$. Begge disse faktorer er afgørende for at kunne betale en husleje i Vancouver, som overførselsindkomsten "invaliditetsydelse" sjældent 
dækker alene. Sameksistensen af psykisk sygdom og stofmisbrug og/eller hjemløshed er rapporteret i den årlige "hjemløse-optælling" i Vancouver (Marshall, 2019). I 2019 konkluderede rapporten at 44\% af byens hjemløse identificerede sig selv med at have psykiske problemer, imens hele 60\% identificerede sig selv som værende stof-afhængig (inklusiv alkohol og cigaretter) (ibid.: 19, 20). Dette bliver dog sjældent italesat i Clubhouse. Det er et vilkår, som Clubhouse forsøger at behandle, men spørgsmålet om, hvorfor nogle er medlemmer i mere end 15 år, forklares ved, at deres sygdom er mere intens, eller at de ikke er nået så langt i deres recovery endnu.

\section{Empirisk felt}

Måden, hvorpå Clubhouse hjælper deres medlemmer mod recovery og mod reintegration i samfundet, er konkret forankret i organisationens daglige rutiner. Dette sker igennem en rekonstruktion af den generelle arbejdsdag, hvor igennem medlemmet "konfronteres med hverdagens rutiner, tilegner sig nye færdigheder og klargøres til at vende tilbage til samfundet" (ibid.).

Feltarbejdet er foretaget fra begyndelsen af april til medio august 2019, hvoraf størstedelen af tiden er brugt i Clubhouse. Sideløbende har jeg besøgt beslægtede organisationer i Vancouver, der havde fokus på hjemløshed og stofmisbrug. I den forbindelse opdagede jeg, at nogle medlemmer var forbundet til mere end en organisation, som desuden havde fokus på at behandle andre problemer end psykisk sygdom. Selvom 'dual issues' i sig selv ikke er atiklens overordnede fokus, er det som tidligere beskrevet alligevel en del af Clubhouse's udfordringer. I en dansk kontekst problematiseres de manglende interaktionsflader mellem psykiatrien og misbrugsbehandlingen, hvilket fører til at de to områder ikke ved, hvem der har ansvaret for at behandle (Johansen, 2018: 126). Det samme gør sig gældende i artiklens empiriske kontekst. Clubhouse må forstås som en decentraliseret støtte til psykiatrisk behandling og er altså ikke placeret i selve psykiatrien. Snarere er Clubhouse-strukturen mere sammenlignelig med anden peer-støtte såsom misbrugsbehandlingen TurningPoint i Vancouver. Disse to organisationer henviser medlemmer og klienter imellem hinanden, hvilket medfører, at det er op til det enkelte individ at bestemme, hvor det hører til. Både disse fortællinger og denne artikel illustrerer således noget om, hvordan patienter gøres til medaktører og dermed pålægges et stort ansvar for deres bedring (se desuden Bjerge \& Nielsen, 2014). Personalet i Clubhouse forventes, ud fra en peer-tankegang, at kunne demonstrere, at de har taget ansvar for deres psykiske bedring, hvorefter medlem- 
merne forventes at tage ved lære heraf. Det betyder dog ikke, at forventningen til personalet er nedskrevet eller italesat. Som jeg senere skal uddybe analytisk ved hjælp af en foucauldiansk tradition, er det netop ved at se på menneskelig adfærd; hvad vi skjuler og hvad vi viser, at de egentlige strukturelle forventninger til mennesket kommer til syne. Artiklen giver således indblik i, hvad der forventes af et menneske med psykisk sygdom, for at vedkommende kan siges at have gennemgået recovery.

\section{Formål}

Med udgangspunkt i baggrundslitteraturen analyserer denne artikel, hvordan personalet i Clubhouse til daglig besidder og demonstrerer en dobbelt rolle af på den ene side at være relaterbar og "lige" med medlemmet, fordi begge parter lider af psykisk sygdom. På den anden side føler personalet, at de skal være forskellig fra medlemmet, fordi den ansatte forventes at være i kontrol over sin egen psykiske sygdom. Artiklen har således til formål at belyse, at Clubhouse's intention om at benytte peer-forbilleder til at opnå recovery, hvor relatérbarheden mellem ansat og medlem må være lighedsskabende, bliver udfordret i den praktiske virkelighed, hvori dette skal finde sted. Argumentet er således, at personalet, for at kunne beholde sin position som den 'guidende', fremstiller sig selv som værende upåvirket af deres sygdomme. Dette demonstrerer et urealistisk billede af, hvad det vil sige at have gennemgået recovery. Snarere end at demonstrere hvilke udfordringer personalet selv lever med, holder de udfordringerne skjult. Argumentet er, at denne handling udvisker det lighedsskabende perspektiv, som er i den peer-tanke, der indledningsvist blev beskrevet af Ethan, hvor medlemmet altså kan spejle sig i den ansattes udfordringer. Forskellen mellem de ansatte og medlemmerne er dermed ikke, om de er syge eller ej, men snarere et udtryk for at nogen evner recovery, og andre ikke gør. Risikoen er, at årsagen til og ansvaret for dette bliver placeret indeni det individ, der ikke gennemgår recovery på det forskønnede niveau og ikke kommer tilbage i samfundet. En yderligere konsekvens kan være, at både medlemmer og personale accepterer denne forklaring og derfor ikke stiller spørgsmålstegn ved, hvorfor mange er medlemmer i 15-30 år. Det kan betyde, at de andre problematikker, der ligeledes kunne lægge til grund for de lange medlemsskaber (hjemløshed, dobbeltdiagnoser og social ulighed), ikke bliver løst, fordi de ikke forstås som en afgørende del af årsagen til problemet. 


\section{Metode}

Feltarbejdet bygger særligt på deltagerobservation og 31 båndede interviews, hvoraf 14 er med medlemmer, og 11 er med personale. De resterende 6 er med to "brugere", der aktivt havde fravalgt et medlemskab i Clubhouse til fordel for organisationer, der fokuserede på misbrugsbehandling. Hvor de fleste interviews er på omkring en times varighed, løber interviewene mellem 20 minutter og 2,5 timer. Derudover har deltagerobservationen i Clubhouse givet anledning til adskillige ikke-båndede samtaler med medlemmer, som ofte var reaktioner på begivenheder indenfor organisationen.

Jeg har ikke interageret med medlemmerne udenfor Clubhouse. Dette har til gengæld været muligt med de to deltagere, der valgte at stå udenfor organisationen. Med disse har jeg deltaget i kommunale initiativer, herunder en række møder (eksempelvis "Belonging Matters" og "Minimum Wage Discussion"), hjemmebesøg, walk-alongs og et Comedy Show med fokus på mental sundhed kaldet "Heavy Mental". Dette har givet mig et indblik i nogle af de tiltag der - snarere end psykisk sygdom - karakteriserer og kritiserer samfundsmæssige problemstillinger som eksempelvis social ulighed.

\section{Præsentation af informanter}

De informanter, som artiklen omhandler, er alle diagnosticeret med psykisk sygdom. Hvor det for de ansatte er psykisk sygdom, der er hovedproblemet, har dele af medlemmerne ligeledes været konfronteret med hjemløshed og/eller stofmisbrug. I et forsøg på at opbygge tillid har jeg i Clubhouse ladet informanterne komme til mig snarere end omvendt. Jeg selv og mit projekt blev præsenteret for personale og medlemmer i feltarbejdets første dage, hvorefter jeg begyndte at arbejde med medlemmer og personale i køkkenet. Efter et par uger efterspurgte individer fra begge grupper at afholde interviews, og om de måtte "fortælle deres historie". Størstedelen af informanterne i dette studie har derved selv vist interesse $i$ at være med, hvorfor det kun er et par stykker af både personale og medlemmer, der har deltaget på min opfordring. Det betyder naturligvis, at studiet risikerer at blive en smule ensidigt, da netop de medlemmer og ansatte, der ikke umiddelbart ønskede at deltage, formodentlig rummer interessante perspektiver. Dette var tilfældet med den ansatte, Christina (der i øvrigt er et pseudonym), som først indvilligede i et interview 3 måneder inde i mit feltarbejde. Under vores interviews var hun yderst opmærksom på ikke at oplyse detaljer, der ville afsløre hendes person, hvis 
det drejede sig om ikke at være i kontrol. Sådanne personlige og mere fortrolige samtaler med personalet afslørede således en analytisk vigtig pointe, nemlig at personalet skjulte aspekter af dem selv og deres psykiske sygdom for at fremstå som altid værende i kontrol.

\section{Analyse}

En af præmisserne for en organisation, der som Clubhouse befinder sig indenfor et paradigme karakteriseret ved recovery (Doyle, 2013: xiv), er, at den benytter sig af "peer-support". I dette paradigme har der i vid udstrækning været tradition for, at personalet er tidligere patienter, der har gennemgået recovery (Rakfeldt et al., 2009: 13). Rationalet er, at tidligere patienter med deres førstehåndsoplevelse bedre kan forstå, hvad patienter gennemgår (ibid.). At have gennemgået recovery må her forstås anderledes end at være sygdomsfri. Recovery handler i stedet om at give mennesker med "alvorlig psykisk sygdom" muligheden for, og retten til, at kunne genskabe et meningsfuldt og produktivt liv (ibid.: 3). Det er ydermere en mulighed, der kan ses som et tveægget sværd, fordi der med muligheden for at kunne genskabe et meningsfuldt og produktivt liv, selvom man lider af psykisk sygdom, følger en forventning og et krav om at gøre det. Den medicinske sociolog Nikolas Rose beskriver, hvordan muligheden for at arbejde med og udvikle på, "'selvet' både giver alle mulige rettigheder og privilegier" men samtidig bringer "adskillelse, byrder, og trives på angsten og skuffelsen som den genererer gennem egne løfter" (Rose, 1996: 3).

Det er Clubhouse's erklæderede formål at "eliminere stigma omkring psykisk sygdom", og det ønsker dertil at hjælpe medlemmer med at "genskabe deres liv igennem et støttende miljø, der fokuserer på den enkeltes styrker og talenter fremfor sygdom" (Pathways Clubhouse, 2018). "Afstigmatisering" er ligeledes fokus for the American Psychiatric Association, der uddyber at "psykisk sygdom ikke er noget at skamme sig over. Det er et medicinsk problem på lige fod med hjertesygdomme og diabetes" (American Psychiatric Association, 2018). Således henter afstigmatiseringen hjemmel i biologien. Sociolog Anthony Giddens har blandt andre beskrevet, hvordan "galskab" med moderniteten blev medikaliseret til at være psykisk sygdom. Med afsæt i kroppens biologi bliver alle mennesker sårbare overfor det biologiske fænomen "psykisk sygdom" (Giddens, 1991: 159). Ifølge Giddens er vi således ikke ansvarlige for at få sygdommen, fordi en sygdom kan "angribe os alle" (ibid.). Jeg skal i denne artikel ikke gå ind i en dybere analyse af neurologiske forståelsesrammer af 
psykisk sygdom (jf. Rose \& Abi-Rached, 2013; Rose, 2018), og jeg skal heller ikke erklære mig hverken enig eller uenig deri. Jeg peger i stedet på, at hvis et problem er karakteriseret som biologisk, må alle, der er underlagt denne biologi, konfronteres med problemet på lige fod. Dette har en praktisk foranstaltning, hvor alle, der er diagnosticeret med psykisk sygdom, i udgangspunktet må være forbundet af en fysisk og biologisk lighed. Samtidig må en sådan forbundenhed og lighed forstås på et abstrakt plan, der ligger i universaliteten af sygdom (jf. Foucault, 1965: x-xi). Det kan således forstås som lighedsskabende at karakterisere psykisk sygdom ved biologi, fordi alle dermed på lige fod kan rammes heraf og derfor ikke tilskrives skylden for sygdommen. I den empiriske kontekst af Clubhouse har dette en konkret forankring, idet både personale og medlemmer er diagnosticeret med psykisk sygdom. I sin abstrakte form kan man sige, at muligheden for recovery er lighedsskabende, fordi mennesker med psykisk sygdom gennem processen af recovery rykker tættere og tættere på dem, der ikke lider af psykisk sygdom.

Det er tilsyneladende ikke det at være psykisk syg, der afgør, om man kan leve "et produktivt og meningsfuldt" liv, når de ansatte på daglig basis demonstrerer, at de mestrer netop dette på trods af deres psykiatriske diagnose. Medlemmet kan altså spejle sig i, at recovery er muligt. Alligevel peger jeg på, at medlemmerne har svært ved at spejle sig i processen, da personalet netop skjuler egne udfordringer, hvilket jeg vil belyse i det følgende afsnit.

\section{Personalets dobbelte rolle}

Ethan var et eksempel på en ansat, der selv led af psykisk sygdom. Han var i begyndelsen af 20'erne og havde været ansat i tre år. Han led af angst og depression, som han stadig var medicineret for. Ethan beskrev personalets rolle på følgende vis:

Vores formål her $i$ Clubhouse er at hiælpe vores klienter med at være hævet over deres psykiske sygdom; at arbejde sig forbi de udfordringer, de står overfor. Jeg har selv kæmpet med psykisk sygdom igennem mit liv, og jeg har fundet forskellige måder at håndtere det på. Det meste af vores klientel har ikke lært, hvordan de skal fungere på trods af deres psykiske sygdom. Jeg håber, at jeg ved at være her, og igennem min erfaring, kan hjælpe dem til at få de samme fxrdigheder, som jeg har.

Citatet rummer, at en ansat bruger egen erfaring til at rådgive, guide og relatere til medlemmet. Hvis den ansatte oplever udfordringer med at håndtere sin psykiske 
sygdom, kan vedkommende altså med fordel dele denne oplevelse med medlemmet for at fremme medlemmets recovery. Dette er dog ikke tilfældet. I tråd med Ethan's citat bliver personalets psykiske sygdom blot et argument for, at de forstår, hvad medlemmet går igennem, og altså ikke noget personale og medlem taler om. De følgende afsnit præsenterer eksempler på, at både Ethan og andre ansatte beskriver, hvordan de skjuler deres udfordringer og ikke gør brug af dem i relation til medlemmerne. Der er naturligvis mulighed for, at personalet kan have den slags samtaler med medlemmet på tomandshånd, dog har jeg aldrig observeret dette i Clubhouse. Når medlemmer har forklaret, hvordan Clubhouse hjalp med at fremme deres recovery, fremhævede de hjælp til bolig, fællesskab med andre medlemmer, struktur i form af daglige rutiner og ganske vist, at personalet var venligt, men ikke at de videregav egne mestringsstrategier. Personalet udtrykte generelt manglende tid til at tale med medlemmerne, fordi de udførte de daglige opgaver og blev derudover frarådet at være alene med medlemmer af sikkerhedsmæssige grunde. De følgende afsnit vil desuden eksemplificere, hvordan personalet nødigt vil virke uprofessionelle ved at dele for meget om deres udfordringer.

Jeg har været meget deprimeret og havde nogle selvmordstanker $i$ går. Det var helt vildt! Men jeg har det bedre i dag, efter jeg fik snakket om det. (Marcel, medlem)

Marcel sad ved spisebordet omgivet af mennesker, der ikke synes at lade sig påvirke særligt af samtalen. Dette stod i stor kontrast til personalet, der kun talte på denne måde, når jeg var alene med dem. Selvom de jævnligt fortalte, at de var åbne om deres psykiatriske diagnoser, understregede de også, at hverken personale eller medlemmer kendte til de detaljer, der blev delt i vores tosomhed. Både Ethan og en ansat, Conrad, havde ligeledes fortalt mig om selvmordstanker, men at disse blev beskrevet som at høre fortiden til. Ethan sagde:

Det gik op for mig, at selvom jeg har haft mange selvmordstanker grundet min depression, har jeg ikke haft dem, siden jeg startede på medicin. Siden da har det handlet mere om selvskade end selvmord. Altså, jeg har ikke villet dø, jeg har bare villet være skadet.

På trods af Ethans udsagn havde han dagen forinden episoden med Marcel udtalt et modstridende udsagn $\mathrm{i}$ et af vores personlige interviews. På tidspunktet for interviewet havde Ethan været på medicin i cirka et år:

Sidste gang, jeg kan huske, at jeg havde selvmordstanker, er cirka for en måned siden. Det var det dummeste - det var bare på grund af vasketøj. Jeg havde glemt at lagge 
det $i$ tørretumbleren, og så sendte min hustru mig sådan et skuffet blik. Jeg ordnede det med det samme, men hendes blik holdte mig vågen hele natten. Og hele næste dag kunne jeg ikke tænkte på andet end at tage min motorcykel ned af afkørslen til motorvejen og så bare stoppe. Men jeg blev ved med at tænke: det er bare vasketøj, det er bare vasketøj.

Selvom den episode Ethan beskriver fandt sted under mit feltarbejde, var jeg ikke klar over det før tre uger efter. I stedet var Ethan sygemeldt med migræne på tidspunktet, hvilket, han i vores personlige samtale forklarede, i virkeligheden var en "mental health day". Man kan her spørge, hvorfor Ethan ikke fortæller åbent om den mentale sygedag men i stedet pakker det ind i fysisk sygdom? Hvorfor er han ikke åben om det faktum, at han i denne periode er meget udfordret af sin depression, eller hvordan han lykkes med at overvinde tankerne? Selvom dette selvfølgelig kan have store udfordringer, når det gælder ansvaret for og beskyttelse af et menneske, der potentielt er til fare for sig selv, skulle man i et peer-støtte-perspektiv synes, at også denne udfordring kunne være værdifuld for medlemmet at dele med den ansatte? Tendensen er desuden at finde på et mere generelt (og mindre enerverende) plan, når det drejer sig om, hvordan ansatte skjuler, at de har udfordringer med angst:

Igennem mine interviews fortalte alle fire ansatte, at deres følelser af angst var for overdrevne og svære at kontrollere til at kunne finde sted i Clubhouse. I den sammenhæng fortalte den ansatte ved navn Christina, at Clubhouse manglede steder, hvor der kun var adgang for personale. Det var nødvendigt for, at man som ansat kunne have en reaktion, man ikke kunne vise medlemmerne:

Natasja: $\quad$ Synes $d u$, at det er en generel ting, når man arbejder med dette område, at man er nødt til at kunne beherske sig selv?

Christina: Ja, man er virkelig nødt til at kunne beherske sig selv!

Natasja: Hvad hois der var en situation her $i$ Clubhouse, hvor du var ved at græde eller blev vred... ville du så være nødt til at forlade stedet?

Christina: $\quad J a$, så er du nødt til at gå ud på badeverelset eller noget $i$ den stil.

Natasja: $\quad$ Er det noget, der sker?

Christina: Det er sket et par gange, ja. I alle de år jeg har arbejdet her, har jeg ikke grædt eller mistet temperamentet overfor et medlem. Men jeg har grædt eller mistet 
temperamentet alene, eller når jeg har talt med andet personale. Jeg ved ikke, om det er godt eller okay, men det sker.

En anden ansat, Conrad, havde muligheden for selv at styre sin arbejdsdag lidt mere, fordi han ofte skulle til møder udenfor Clubhouse. Han fortalte, at møderne indimellem var et dække over, at han havde et angstanfald som ingen måtte se:

Når jeg tager afsted herfra, føler jeg, at jeg fortjener en Oscar, for jeg er ved at dø. Jeg siger "Åh, telefonen ringede lige, og jeg er nødt til at løbe, vi ses senere," og så stempler jeg ud. Folk har ingen idé. Enten tager jeg hjem, eller også kører jeg en tur først. I de fleste tilfxlde parkerer jeg bare henne ved storcentret og sidder der i bilen. Jeg er meget påpasselig med ikke at parkere for tæt på nogen andre, hvor de ville kunne se mig. Så sidder jeg der og venter på at panikken forsvinder. Nogle gange er jeg nødt til at tage noget beroligende medicin. Somme tider kommer jeg tilbage og siger, at mødet er overstået. Jeg vil ikke opføre mig som jeg føler her $i$ Clubhouse. Folk vil tænke: "Dén ansatte har en virkelig dårlig dag, og han har svart ved at kontrollere det.

Ovenstående empiri udgør eksempler på, hvordan personalet føler, at der er bestemt adfærd, man ikke bør vise i Clubhouse. Selvom Clubhouse ytrer ønsker om åbenhed, afstigmatisering og lighed mellem personale og medlem, er der tilsyneladende en uoverensstemmelse i mellem ønske og handling. Som en antropologisk kliché kan man fremhæve vigtigheden af, at se på forskellen mellem hvad mennesker gør, og hvad de siger, at de gør. Ikke desto mindre er det meget relevant i dette tilfælde. Vi opdager, at personalets udsagn, om at bruge egen erfaring til at fremme medlemmernes recovery, ikke stemmer overens med det, de gør i praksis. For at vide at personalet faktisk har en erfaring at dele ud af, må man som etnograf have en vis fortrolighed med det givne personale. Pointen er, at artiklens empiri har eksempler på fire ansatte, som fortæller om deres erfaringer i vores private samtaler men ikke bruger dem i relation til medlemmet. Artiklen kan således ikke besvare, om samme er gældende for de resterende tolv ansatte, fordi det kræver en fortrolighed, jeg kun har haft med de pågældende fire.

Jeg har belyst, at der i den biologiske forståelse af psykisk sygdom ligger en implicit idé om lighed, fordi det er noget, der kan ramme alle. Tilmed har jeg peget på, at der er en idé om lighed i betragtningen af, at medlemmer kan spejle sig i de ansatte, der ligesom dem selv er diagnosticeret med psykisk sygdom. Denne mulighed for spejling skal vise, at recovery er muligt, og det skal virke motiverende for medlemmet. Med afsæt i de tre fremlagte eksempler på ansatte, der skjuler, at de har udfordringer med deres sygdom, vil jeg argumentere for, at der sker en 
skævvridning af, hvad det vil sige at leve et meningsfuldt, produktivt og assimileret liv med psykisk sygdom, eller med andre ord: to recover. Skævvridningen sker, fordi medlemmet ikke oplever, at livet med psykisk sygdom rummer udfordringer. Fremfor at vise hvordan livet med psykisk sygdom kan indebære at være nødsaget til at trække sig fra en situation, at måtte forlade organisationen i situationer med angst, eller at have svære depressive perioder med oplevelser af selvmordstanker, fremstår personalet som værende relativt ubesværede af deres sygdomme. Personalet viser således kun dele af, hvordan recovery fra psykisk sygdom ser ud, hvilket gør det svært for medlemmet at spejle sig i. Hvad der burde være et spejl, der viste ligheder mellem personale og medlemmer og deres fælles oplevelse med psykisk sygdom, bliver spejlbilledet nu slørret af, hvad der ligner forskelle; nemlig at nogen udfordres og mister kontrol med deres sygdom, og andre ikke gør.

\section{Forventninger til forskønnede forbilleder}

Man fristes måske til at spørge, hvorfor personalet ikke blot deler deres udfordringer med medlemmet? Foruden at det selvfølgelig kan have en praktisk udfordring, at begge parter er meget besværede af deres sygdomme på samme tid, vil jeg endvidere se nærmere på en mere teoretisk forklaring. I artiklens begyndelse placerede jeg mig teoretisk i en foucauldiansk tilgang, hvori individet forstås som et subjekt, der kan regulere sig selv. Jeg har påpeget, at individet, for at kunne modtage hjælp indenfor denne behandlingsstruktur af åbne organisationer, frivilligt må indgå i recovery-behandling. Allerede før behandlingen påbegyndes, rummer denne behandlingsstruktur, som Clubhouse er placeret i, altså en forventning om, at individet er et selvregulerende subjekt - eller et subjekt, der indvilliger i at være lære selvreguleringens kunst. Ser vi nærmere på, hvordan recovery-paradigmet forholder sig til subjektets evner til selvregulering, skriver den amerikanske psykolog Patricia Deegan, at et individ, der har gennemgået recovery, forventes at have opnået en nyerhvervet forståelse af sig selv, der indebærer, at individet kan navigere og særligt kontrollere sig selv i denne nye tilværelse (Deegan, 1988). Man kunne derfor overveje, om årsagen, til at personalet skjuler, at også de oplever udfordringer med at kontrollere sig selv i tilværelsen som den guidende peer-støtte, i sig selv er en selvregulering for at kunne leve op til deres rolle? I det følgende vil jeg præsentere, hvordan der er en udtalt forventning til personalets selvkontrol i dette Clubhouse: 
Dave havde været en del af organisationen siden 1984 og havde de sidste mange år besiddet positionen som direktør. Ligesom Ethan var han diagnosticeret med angst og depression, hvilket han fortalte åbent om i Clubhouse. Dave var i begyndelsen af 60'erne og gjorde en dyd ud af at grine med både medlemmer og personale. I et interview hvor Dave og jeg talte om, hvordan det fungerede når personalet også havde psykisk sygdom, sagde han følgende:

Dave: $\quad$ Jeg siger som regel: "Same same, but different.". Jeg har forventninger til personalet. Vi (personale og medlemmer) er "peers" og partnere. Vi er lige, men på nogle punkter er vi ikke lige. Personalet bliver betalt og har bundlinjer, såsom; hvad hvis ingen gider at lave frokost den dag? Så selvom vi i Clubhouse taler meget om lighed, er vi ikke lige. Det betyder ikke, at de ansatte ikke har en psykisk sygdom eller mentale udfordringer, men om hvordan man, når man arbejder her, er nødt til at være anderledes. Nogle medlemmer kan måske ikke lide andre medlemmer, og så behøver de ikke at interagere med hinanden. Der er også nogle af medlemmerne, som jeg ikke kan lide, men jeg er nødt til at interagere med dem, for det er mit job. De behøver bare ikke at vide, at jeg ikke kan lide dem.

Natasja: Handler det om, at man skal kunne skjule, hoad man føler?

Dave: $\quad$ Ja, jeg skjuler, hvad jeg føler!

Natasja: Og det tænker du, at personalet skal?

Dave: $\quad$ Absolut, for hois du udtrykker, hoad du foler overfor medlemmer, bliver det automatisk den service, de fär, og sådan skal det ikke være. Jeg synes ikke, at man skal skjule, hoad man foler hele tiden, men jeg synes man skal udtrykke det til bestemte mennesker og på en måde, der stadig er respektfuld.

Forventningen til, at personalet er i stand til at regulere sig selv, italesættes således i interviewet med Dave. Derudover beskriver Ethan, at der er en dobbelthed i personalets rolle, når den også indebærer at guide og vejlede medlemmer mod recovery. Hvor personalets psykiske sygdom danner grundlaget for en lighed mellem personale og medlem, konnoterer personalets mulighed for at rette og vejlede medlemmer en forskel mellem de to. Ethan forklarer følgende:

Det er samtidigt personalets funktion at agere dommere $i$ Clubhouse, fordi mennesker med psykisk sygdom, jeg selv inklusiv, ikke har de bedste filtre. De bliver derfor nødt 
til at få det at vide, når de siger eller gør noget, der virkelig er upassende, og det er personalets job.

Det er her vigtigt at påpege, at personalets guidende position ikke er givet ved deres titel alene. Det er med andre ord ikke blot fordi, man er personale, at man har mulighed for at guide og rette på medlemmer. I Clubhouse bruger Ethan sin erfaring til at guide og relatere til medlemmer, men han har kun en sådan autoritet, så længe han selv lever op til kravene om at kunne håndtere sig selv. Med andre ord kan man sige, at det er, hvis en ansat selv lever op til den givne standard for selvkontrol, at vedkommende har mulighed for at statuere det gode eksempel (jf. også Foucault, 1985: 25-27).

I forlængelse af artiklens analytiske afsæt $\mathrm{i}$ forståelsen af individet som det selvregulerende subjekt vil jeg igen fremhæve en foucauldiansk tilgang. I andet bind af Seksualitetens Historie: Brugen af Nydelserne beskriver Foucault, hvordan den gældende standard for opførsel ('standard of conduct') ikke blot må forstås som doktriner eller udtalte retningslinjer (Foucault, 1985: 25). Det er en standard, som individet må forholde sig til, og op imod hvilken han/hun må dømme sig selv som enten værende i overensstemmelse med eller værende "syg, gal, eller kriminel" i forhold til (ibid.: 7). Standarder for opførsel er derfor at finde i "individers faktiske adfærd i relation til de regler og værdier, der er dem anbefalet" (ibid.: 25). Så når denne artikel undrer sig over, hvorfor personalet ikke bruger deres erfaring med udfordringer ved psykisk sygdom til at relatere til medlemmer og til at demonstrere, hvorledes disse udfordringer er en del af livet med psykisk sygdom, finder vi ikke nødvendigvis svaret i doktrin eller i udtalte retningslinjer. Med andre ord står det altså ingen steder skrevet, at man som ansat ikke må være besværet af sin sygdom. Alligevel viser materialet, at personalet oplever udfordringer ved og arbejder hårdt på at skjule deres udfordringer. For at undersøge hvorfor må vi altså lede efter svaret i personalets selvregulerende adfærd. Et individ kan leve mere eller mindre i overensstemmelse med en given standard for opførsel, og hvis vedkommende betragter sig selv som "en arving" til denne standard, kan vedkommende "vise troskab hertil, ved at tilbyde sig selv som et eksempel". Individet kan således forsøge at give sit personlige liv en form, der er i perfekt overensstemmelse med standardens kriterier for, hvad der må forstås som et moralsk - og dermed godt - liv (Foucault, 1985: 27). Følger vi denne logik, må et individ leve op til en standard for at kunne guide et individ, der ikke gør. Med andre ord må en ansat, hvis formål det er, at demonstrere hvordan man lever et almindeligt, produktivt liv i assimilation med resten af samfundet, altså kunne demonstrere dette. Udfordringen er, at 
dette fremviste forskønnede peer-forbillede skaber et misvisende billede af, hvad det vil sige at leve med psykisk sygdom.

\section{Accept af manglende reintegration?}

Afslutningsvist kunne man fristes til at spørge om og hvordan, dette forskønnede og misvisende forbillede har betydning for medlemmerne? Med andre ord: hvad er konsekvensen? Dette er et spørgsmål, der forfulgte mig under, og længe efter, feltarbejdets afslutning. Spørgsmålet udsprang af, at de fleste af medlemmerne enten ikke deltog i de daglige opgaver eller opfyldte den samme specifikke opgave hver dag, i 5, 10, 20 og 30 år. I særdeleshed undrede jeg mig over, hvorfor hverken medlemmer eller ansatte stillede dette spørgsmål, men accepterede at den ønskede reintegration ikke lykkedes? En dag, da Ethan og jeg talte om, hvordan Clubhouse hjalp mennesker igennem recovery og tilbage i samfundet, sagde han:

Ethan: $\quad$ Når du holder ferie, tager du en pause fra verden. Du holder en pause fra dine problemer, du beroliger dig selv og giver slip. Når du kommer tilbage til dit liv, er det med fornyet energi og et klarere sind. Det er det samme Clubhouse gør. Det er som en miniferie, hoor man kan slappe af og dygtiggøre sig, så man kan forlade Clubhouse og vende tilbage til verden klar til tage dens udfordringer op.

Natasja: $\quad$ Men hoad så med de medlemmer, der er her i 20-30 år?

Ethan: $\quad$ Nogle mennesker har bare brug for det længere.

Snarere end et henvise til strukturelle problemer som hjemløshed, komplikationer med at behandle dobbeltdiagnosticerede, skævvridninger mellem boligpriser og mindsteløn og andre socioøkonomiske forhold, peger Ethan på individet som forklaringen på, at nogle er medlemmer af Clubhouse i 20-30 år. Så når artiklen ikke direkte præsenterer data, hvor medlemmer fortæller om ikke at kunne leve op til den standard for selvkontrol og manglende besvær med sin sygdom, som personalet demonstrerer, er netop manglen på data vigtig. En analyse kan være, at medlemmer og ansatte kommer til at acceptere, at mange medlemmer ikke reintegreres i samfundet selv efter mange år. Jeg har igennem artiklen påpeget, at personalet kan komme til at skævvride billedet af, hvad det vil sige at have gennemgået recovery og leve hensigtsmæssigt med psykisk sygdom, når de gemmer deres udfordringer for medlemmerne. Jeg har ydermere påpeget, at det kan se ud 
som om nogle evner recovery, og andre ikke gør. Med afsæt i Ethan's sidste kommentar understreger jeg en problematisering af, hvorvidt arbejdet med recovery baseret på peer-forbilleder giver resultater i form af assimilation og tilbagevenden til et normalt liv. Personalet føler sig nødsaget til at forskønne deres egen recovery for at kunne beholde sin guidende rolle. Deres forskønnede forbillede kan få det til at ligne, at man kan lykkes med recovery og reintegreres i samfundet, hvorved samfundets forhold, normer og rammer ikke behøver at blive ændret. Man kunne således frygte, at skævvridningen af recovery er medvirkende til, at både medlemmer og personale accepterer, at mange medlemmer lever deres liv indeni organisationen - og forbliver i de samme problemer.

\section{Konklusion}

Denne artikel foregår i et Clubhouse, der tror på, at mennesker med psykisk sygdom kan komme til at leve produktive liv på lige fod med resten af samfundet. Organisationen placerer sig således indenfor et paradigme af recovery. Metoden hertil bygger på peer-støtte, hvor mennesker, der selv lider af psykisk sygdom, bruger deres erfaring til 1) at demonstrere at man kan leve et normalt og produktivt liv med psykisk sygdom eller med andre ord, at recovery er muligt, og 2) at guide til hvordan dette lader sig gøre. Alligevel præsenterer artiklen en virkelighed, hvor 1) medlemmerne forbliver medlemmer, og hvor det kan diskuteres, om der sker en fremdrift $i$ form af assimilation eller snarere en accept af problemforhold og 2) hvor personalets - $i$ teorien fordelagtige - baggrund med psykiske problemer $i$ flere tilfælde resulterer i det modsatte af åbenhed, og gør at personalet har svært ved både at praktisere deres job og opretholde deres position.

Rationalet om, at personalet bedre kan relatere til medlemmet, fordi også personalet oplever udfordringer ved psykisk sygdom, bliver givetvis praktiseret. Personalet kan altså spejle sig i medlemmet, men dette gør sig ikke gældende den anden vej, så længe medlemmet ikke får at se, at også personalet oplever udfordringer. I peer-support øjemed skulle spejlingen helst foregå således, at den, der endnu ikke har gennemgået recovery, kan spejle sig i den, der har. Men i denne empiri undlader personalet i Clubhouse at vise de dele af deres virkelighed, hvor de fortsat er udfordrede af deres sygdom, hvilket skævvrider betydningen af, hvad det vil sige at leve et godt liv med psykisk sygdom. Med andre ord fremviser personalet altså en version af sig selv, der er længere fra medlemmet, end det faktisk er tilfældet, hvorved en spejling vanskeliggøres. Man kunne derfor overveje, 
om det ville være gavnligt for Clubhouse og andre peer-støtte-organisationer, at personalet i højere grad var åbne omkring deres udfordringer med psykisk sygdom? Selvom tanken bag peer-støtte allerede har taget et stort skridt imod at minimere et skel og et hierarki mellem dem, der guider, og dem, der bliver guidet, bør man overveje, hvorvidt det faktisk er det, der sker i praksis. Artiklen her er et eksempel på en virkelighed, der ikke stemmer overens med intentionen, hvorved den lægger op til at overveje, om samme gør sig gældende i øvrige peer-support sammenhænge. Man fristes til at spørge, om Clubhouse og andre lignende foranstaltninger kommer til at acceptere, at forklaringen er, at nogle mennesker ikke evner recovery? I accepten af at nogen er medlemmer i 20-30 år, kan systemets umiddelbart succesfulde men stærkt forskønnede peer-forbilleder lede til den konklusion, at medlemmerne selv bærer ansvaret for den manglende reintegration til et assimileret liv. Artiklens teoretiske afsæt pegede på, at både "recovery" og "problem-identiteter" afkræver et individ, der tager ansvar for egen bedring og reintegration - eller med andre ord, at medlemmet skabes som et selvregulerende subjekt for at blive i en foucauldiansk terminologi. Når personalet forskønner deres egen recovery og dermed demonstrerer, at samfundets kontekst ikke er en afgørende faktor, formindskes det rette incitament til at forbedre de forhold, som ligger udenfor individet. Med andre ord kan personalets forskønnelse af sig selv bidrage til en reproduktion af at behandle individer som problem-identiteter snarere end at se på, hvilke samfundsmæssige forhold, der skaber og/eller fastholder nogle individer og identiteter i problemer. Jeg håber, artiklen kan bidrage til, at vi ikke ukritisk kommer til at acceptere, at nogle mennesker ikke evner recovery, uden at vi spørger om hvorfor - eller om årsagen kunne findes udenfor individet?

\section{Referencer}

American psychiatric association. (2018). What is Mental Illness? Last accessed April 10th, 2020. https://www.psychiatry.org/patients-families/what-is-mental-illness

Bjerge, Bagga \& Nielsen, Bjarke. (2014). Empowered and Self-Managing Users in Methadone Treatment? European Journal of Social Work 17.1, 74-87.

Bourgois, Philippe I., and Jeff Schonberg. (2009). Righteous Dopefiend. Berkeley: University of California Press.

Chin, Laura. (2019). Pathways Clubhouse Financial Review. Last accessed September 1st 2020. https://www.charityintelligence.ca/charity-details/144-pathwaysclubhouse?fbclid=IwAR0SWVOnTe4_y9F1JzE2v0Rig2eoAJ13I0OIWmUCkamIB_A9i PcsEulqreU 
Deegan, P. E. (1988). Recovery: The lived experience of rehabilitation. Psychosocial Rehabilitation Journal, 11(4), 11-19.

Doyle, Allan; Lanoil, Julius \& Dudek, Kenneth. (2013). Fountain House: creating community in mental health practice. New York: Columbia University Press.

Foucault, Michel. (1965). Madness and Civilization: A History of Insanity in the Age of Reason. New York: Vintage Books. Pp. V-84.

Foucault, Michel. (1985). The Use of Pleasure. Volume Two of The History of Sexuality. New York: Vintage Books.

Foucault, Michel. (1991). Governmentality. In G. Burchell, C. Gordon and P. Miller (eds). The Foucault Effect: Studies in Governmentality. London: Harvester Wheatsheaf, pp. 87-104.

Giddens, Anthony. (1991). Modernity and self-identity: self and society in late modern age. Cambridge Policy.

Goffman, Erving. (1961). Asylums: Essays on the social situation of mental patients and other inmates. Antony Rowe Ltd, Chippenham, Wiltshire.

Gubrium, J.F. \& J.A Holstein. (2001). Introduction; trying times, troubled selves. In J.F. Gubrium \& J.A Holstein: Institutional selves. Troubled identities in a postmodern work. New York: Oxford University Press.

Hacking, Ian. (1986). Making up people. In T.C: Heller, M. Sosna \& D.E. Welby: Reconstructing individualsm. Stanford, CA: standard University Press.

Holstein, J.A. \& G. Miller. (1993). Social Constructionism and social problems work. In Holstein, J.A. \& G. Miller: Reconsidering social constructionism, Debates in social problems theory. New York: Aldine de Gruyter.

Johansen, K. S.; Busch, S.; Pinderup, P.; Mårtensson, S.; Poulsen, H. \& Larsen, J. L. (2018). Dobbeltdiagnosepatienters Møde Med Det Psykiatriske Behandlingssystem. Tidsskrift for Forskning i Sygdom og Samfund 15.28 (2018), 155-172.

Johansen, K. S. (2018.) Treatment of Dual diagnosis in Denmark - Models for Cooperation and Positions of Power. Qualitative Studies, vol. 5, nr. 2, 125-139.

Järvinen, Margaretha \& Mik-Meyer, Nanna. (2003). Indledning: At skabe en klient. In Järvinen, M. \& Mik-Meyer, N. (red): At skabe en klient: Institutionelle identiteter $i$ socialt arbejde, 9-29. København. Hans Reitzels forlag.

Jöhncke, S.; Svendsen, M. N. \& Whyte, S. R. (2004). Løsningsmodeller. Sociale teknologier som antropologisk arbejdsfelt. In K. Hastrup (red.), Viden om verden. En grundbog $i$ antropologisk analyse, 385-407. København: Hans Reitzels Forlag.

Marshall, Claire. (2019). Homeless Count. City of Vancouver. Last accessed September 26, 2019. https://council.vancouver.ca/20190612/documents/pspcla-Presentation.pdf

Oute, Jeppe \& Bjerge, Bagga. (2017). “What Role Does Employment Play in Dual Recovery? A Qualitative Meta-Synthesis of Cross-Cutting Studies Treating Substance Use Treatment, Psychiatry and Unemployment Services." Advances in Dual Diagnosis 10.3: 105-119.

Pathways Clubhouse. (2018). Our Mission. Last accessed April 10th 2020. https://pathwaysclubhouse.com/about/our-mission/

Rakfeldt, Jaak.; Davidson, Larry \& Strauss, John S. (2009). The Roots of the Recovery Movement. In Psychiatry: Lessons Learned. Chicester, West Sussex, UK: Wiley- Blackwell.

Ronquillo, Charlene. (2009). Deinstitutionalization of mental health care in British Columbia: a critical examination of the role of Riverview Hospital from 1950 to 2000. University of British Columbia. 
Rose, Nikolas. (1996). Inventing our selves: Psychology, power and personhood. Cambridge University Press. United Kingdom.

Rose, Nikolas \& Abi-Rached, Joelle M. (2013). Neuro: the new brain sciences and the management of the mind. Princeton, N.J.: Princeton University Press.

Rose, Nikolas. (2018). Our Psychiatric Future. Newark: Polity Press.

Rouse, Carolyn. (2010). Patient and Practitioner Noncompliance: Rationing, Resistance, and the Missing Conversation. Anthropology and Medicine, 17(2), 187-200. 